\title{
Eurocentric influences on the Brazilian Advertising Self-Regulation System: historical research from a decolonial perspective
}

\author{
LAÍS RODRIGUES ${ }^{1}$ \\ MARCUS WILCOX HEMAIS ${ }^{1}$ \\ ${ }^{1}$ Pontifícia UnIVERsidade CATÓLICA do RIO DE JANEIRO (PUC-RIO), RIO DE JANEIRO, RJ - BRAZIL
}

\begin{abstract}
This study aims to analyze, from a decolonial perspective, imperialist historical processes that made possible the incorporation of the Eurocentric self-regulation model adopted in the creation of the Brazilian Advertising Self-Regulation System, SBAP. Ahistorical research was carried out, based on the critical perspective, using secondary data to analyze this specific case. The analysis shows that the incorporation of foreign elements into the Brazilian system occurred mainly through three factors: the creation and internationalization of a model of advertising self-regulation through ethnocentric and imperial processes; the formation of Brazilian advertising sector according to international standards, especially US standards; and the influence of international models and organizations in relation to SBAP authors. In addition to the discussion focused on the power of companies over consumers, this critical view is expected to generate more knowledge about the relations between the Global North and the Global South and how imperial control materializes in consumerism. Colonial and ethnocentric historical processes limit ways of thinking distinct from the neoliberal logic of consumer protection through free markets, thus helping to maintain Eurocentric dominance over knowledge.
\end{abstract}

Keywords: Consumerism. Advertising. Self-regulation. Decolonialism.

\section{Influências eurocêntricas no Sistema Brasileiro de Autorregulamentação Publicitária: pesquisa histórica sob uma perspectiva decolonial}

\section{Resumo}

Este estudo tem por objetivo analisar, com base na perspectiva decolonial, processos históricos imperialistas que possibilitaram a incorporação de um modelo eurocêntrico de autorregulamentação na criação do Sistema Brasileiro de Autorregulamentação Publicitária, o SBAP. Para isso, foi realizada uma pesquisa histórica, calcada na óptica crítica em questão, utilizando dados secundários para analisar esse caso específico. A análise mostra que a incorporação de elementos estrangeiros ao sistema brasileiro ocorreu por meio, sobretudo, de três fatores: criação e internacionalização de modelo de autorregulamentação publicitária por meio de processos etnocêntricos e imperiais, formação do setor publicitário brasileiro de acordo com padrões internacionais, em especial estadunidenses, e influência de modelos e organizações internacionais em relação aos autores do SBAP. Mais do que uma discussão focada no poder de empresas sobre consumidores, espera-se que essa visão crítica gere mais conhecimento sobre as relações entre o Norte e o Sul globais, bem como de que maneira o controle imperial se materializa em consumerismo. Processos históricos coloniais e etnocêntricos limitam formas de pensar distintas à lógica neoliberal de defesa do consumidor por meio de livres mercados, ajudando, assim, a manter o domínio eurocêntrico sobre o conhecimento.

Palavras-chave: Consumerismo. Publicidade. Autorregulamentação. Decolonialismo.

\section{Influencias eurocéntricas en el Sistema Brasileño de Autorregulación Publicitaria: investigación histórica desde} una perspectiva decolonial

\section{Resumen}

Este estudio tiene como objetivo analizar, desde una perspectiva decolonial, los procesos históricos imperialistas que hicieron posible la incorporación del modelo de autorregulación eurocéntrico en la creación del Sistema Brasileño de Autorregulación Publicitaria, SBAP. Para ello, se llevó a cabo una investigación histórica, basada en la perspectiva crítica en cuestión, utilizando datos secundarios para analizar este caso específico. El análisis muestra que la incorporación de elementos extranjeros al sistema brasileño se produjo principalmente a través de tres factores: la creación e internacionalización de un modelo de autorregulación publicitaria a través de procesos etnocéntricos e imperiales; la formación del sector publicitario brasileño de acuerdo con los estándares internacionales, especialmente los estadounidenses; y la influencia de modelos y organizaciones internacionales con relación a los autores del SBAP. Más que una discusión centrada en el poder de las empresas sobre los consumidores, se espera que esta visión crítica genere más conocimiento sobre las relaciones entre el Norte Global y el Sur Global y sobre cómo se materializa el control imperial en el consumerismo. Los procesos históricos coloniales y etnocéntricos limitan las formas de pensar distintas de la lógica neoliberal de la protección del consumidor a través de los mercados libres, lo que ayuda a mantener el dominio eurocéntrico sobre el conocimiento.

Palabras clave: Consumerismo. Publicidad. Autorregulación. Decolonialismo. 


\section{INTRODUCTION}

According to authors from more mainstream traditions, consumerism is a term used to represent waves of social and political movements involving the defense of consumers, and which initially occurred in the United States (GLICKMAN, 2009; HILTON, 2008; ROTFELD, 2010). The consumerist movement, as it is understood today, began in countries in the Global North during the Industrial Revolution (HILTON, 2007b) and ended up universalizing understanding and consumption according to the logic of those nations (LANDER, 2005). Along with consumerism, the first corporate defense entities emerged, which supposedly had consumer protection as its missions. Two such entities were the International Chamber of Commerce (ICC) (KELLY, 2005) and the International Advertising Association (IAA) (ROTFELD, 2011), both formed by elitist members of nations of the North, who imposed their ethnocentric principles and models on other parts of the world (TOMASHOT, 2015; ROTFELD, 2011).

The consolidation of the consumer movement, which emerged with the discourse that its objective was to protect consumers against corporate abuse (HILTON, 2009), reached its peak after the end of World War II, when the Eurocentric world was facing the Soviet threat to its global dominance, especially during the Cold War (GRANDIN, 2010). The objective was to use consumerism as a convincing tool to show "allies," especially those from the Third World, just how advanced the economies and societies that adopted consumerist-capitalist practices were, when compared to their peers that followed the "backward" communist regime (DURAND, 2008; HILTON, 2009). This picture was reinforced as consumer associations began proliferating in the United States and in Europe, which also expanded its consumerist-capitalist ideals to other non-capitalist regions (COHEN, 2003).

Measures that sought greater regulation to protect consumers, however, suffered reactions within both the United States and Europe, amid questions about the effectiveness of regulation by the state (HILTON, 2009). Beginning in the 1970s, neoliberal ideals were consolidated in the global North, promising growth for all - and, consequently, consumer protection - by means of free markets (HARVEY, 2011). Aligning with such interests, consumer and corporate organizations began entailing neoliberal agendas (HILTON, 2008), with the consequent drawing up of norms involving content that would guarantee the greatest possible freedom of action for the business community (DURAND, 2003, 2008).

This neoliberal framework opened the way for the theme of self-regulation to come to the fore, especially in the advertising sector, which became the topic of interest among marketing academics (ROTFELD, 2011). In a context favorable to the discussion of self-regulation, the advertising self-regulation code created in 1937 by the ICC - an organization founded shortly after the end of the First World War for the purpose of defending companies (KELLY, 2005) - began to be disseminated and implemented internationally (ICC, 2020).

Systems based on the ICC model included a self-regulation code and an agency responsible for applying it (PASQUALOTTO and CAUDURO, 2016). In this way, the ICC was the creator of the code that would directly influence the Brazilian Advertising Self-Regulation Code (Código Brasileiro de Autorregulamentação Publicitária-CBAP) (CONAR, 1978), which would be the basis for the performance of the National Advertising Self-Regulation Council (Conselho Nacional de Autorregulamentação Publicitária - Conar) (SCHNEIDER, 2005). On the other hand, the IAA was responsible for disseminating the self-regulatory system around the world (ROTFELD, 2011; IAA, 2020a), including in Brazil (CONAR, 2020). One of IAA's missions was the defense of the international advertising sector (IAA 2020b).

In Brazil, the topic of consumerism emerged in the 1970s, both externally due to influence by foreign organizations and activists (CAVALCANTI, 2008) and internally due to the development of the consumer goods industry in the country (DURAND, 2008). During this period, there was an increase in discussions involving topics related to consumer protection in newspapers, congresses (ZULZKE, 1997) and even in the National Congress. These topics and discussions were guided and encouraged by the U.S. consumer movements led by Ralph Nader (JOVENS, 1970), one of the main activists of the time, generating a negative reaction by certain Brazilian neoliberals (BETING, 1971), who referred to consumerism as an "evil to be avoided" (CONSUMERISMO, 1974). Such a reaction was similar to that observed in the United States by New Right conservatives (GLICKMAN, 2009).

In the international context, Brazil was a fundamental country to be brought in line with free market capitalist ideals because it could serve as a model for other countries in the region at a time marked by the presence of Latin American political regimes with leftist inclinations (TOTA, 2000; CAVALCANTI and ACALDIPANI, 2016). To guarantee success, a specific appeal was made to the Brazilian advertising sector during the 25th IAA World Congress, held in Buenos Aires in 1976, to encourage it to create its own advertising self-regulation system (DOMINGUES, 1978). The system was also intended to include an agency that would apply the code - in the Brazilian case, Conar (PASQUALOTTO and CAUDURO, 2016). 
Encouraged by the incentives of the IAA and the military government, a group comprised of representatives from advertising entities was brought together to draft the Brazilian code, CBAP (CORRÊA, 1990). SBAP, a Brazilian system that included CBAP and Conar, would be approved at the 3rd Brazilian Congress on Advertising (III Congresso Brasileiro de Propaganda) in April 1978 (AUTORREGULAMENTAÇÃO, 1978). The IAA secretary general at the time gave a speech in celebration of CBAP's approval, explaining that the recommendation made to Brazil served to pressure not only the private sector, but also the Brazilian authorities (CAVALCANTI, 2008). Months later, the IAA would introduce CBAP at the Copenhagen conference as a model to be followed by countries that had not yet adopted the system (DOMINGUES, 1990).

The mainstream marketing literature barely discusses such geopolitical issues related to consumerism. In general, the area has been restricted historically to debating the consumer movement through a lens that puts consumers and companies in an asymmetric power struggle, leaving it to governments to interfere in this relationship in order to make it less hierarchically distorted (KOTLER, 1972). By ignoring the aspects discussed here, marketing fails to consider that consumerism may be interpreted as a form of colonialism through which the Global North seeks to maintain control over the Global South (ESCOBAR, 2004). In the specific case of Brazil, the effects of this process created a "superficial modernization in which the problems inherited by colonialism are still present in Brazilian society" (ROSA and ALCADIPANI, 2013).

The present study is in line with this critical view and aims to analyze, from the decolonial perspective, the historical imperialist processes that made it possible to incorporate a Eurocentric model of self-control in the creation of the Brazilian self-regulation system formed by CBAP and Conar. In order to understand the imperialist processes that gave rise to SBAP, the research also had the specific objective of analyzing the imperialist processes of creating and internationalizing a supposedly "universal" model of advertising self-regulation, presenting a brief history of the formation of Brazilian advertising, which took place via ethnocentric and colonial bases.

The use of the decolonial perspective to analyze this case in particular is intended as a way to contribute a new look at the reasons for the adoption of Eurocentric standards within the Brazilian reality (CAVALCANTI and ACALDIPANI, 2016). This critical view is more than just a discussion focused on the power of companies over consumers; it is hoped that it will generate more knowledge about the relations between the Global North and the Global South, as well as demonstrate the way that colonial control is materialized in consumerism (QUIJANO, 2005).

The rest of the article is divided into four more sections. The next one briefly presents the decolonial perspective, especially the colonialities of power, knowledge and being. The third section of the article presents the study's methodological choices. The fourth entails an analysis in which the main influences of foreign entities and models, generally led by the United States, are exposed in the development of SBAP. Lastly, the fifth section contains the concluding remarks.

\section{SHEDDING LIGHT ON THE DARK SIDE OF MODERNITY: COLONIALITY OF POWER, KNOWLEDGE} AND BEING

The decolonial perspective argues that, since 1492, the Eurocentric world has been expanding modernity as a way to develop the rest of the world and bring it in line with the standard of the Global North. However, while expanding such ideals, modernity carries with it another facet, a dark side called "coloniality," which advances an "irrational praxis of violence" (DUSSEL, 2000) as a justification for imposing a type of development that historically has not helped colonized peoples exit the state of "backwardness" attributed to them (MIGNOLO, 2011).

Modernity/coloniality is instigated in order to create a dichotomy between colonizers and colonized (CASTRO-GÓMEZ, 2008). Since they are culturally superior - at least from the Eurocentric perspective - colonists, in theory, have the right to colonize "inferior" peoples (DUSSEL, 1993). Thus, they classify entire nations according to race, differentiating between the evolved (from the Global North) and the uncivilized (from the Global South), thus creating a racism that defines colonizers as superior (MALDONADO-TORRES, 2018). Therefore, the colonized are left only with a linear perspective imposed by their colonizers, but which makes little sense to the colonized (MIGNOLO and WALSH, 2018).

Such an imposition enables knowledge to be expanded globally as if it were universal (CASTRO-GOMÉZ, 2017), transforming it into something superficial and falsely homogeneous (MALDONADO-TORRES, 2019), which worsened when Eurocentric modernity started to apply the supposed laws of nature to the more complex laws of society (SANTOS, 2009). 
However, Eurocentric knowledge is not universal; it is located in the Global North and is imposed on the rest of the world as the only valid form of thinking. It seeks to discourage any attempts to develop local knowledge aimed at escaping Eurocentric ideologies (MIGNOLO, 2009).

Modernity, as a neutral and universalizable model, is just a myth; it is, in its origin, a justification that seeks to legitimize violence and genocide (DUSSEL, 1993). When the central role of relations among spaces in the rise of the modern world is ignored, the colonial experience and the colonized individual are excluded from the discussion. The colonized therefore become a product of the coloniality of power, knowledge and being (MALDONADO-TORRES, 2008).

In the logic of the coloniality of power, the colonizers impose their idea of development and progress on the colonized by means of ideological dichotomies that racially distinguish between the former, who are seen as civilized and advanced, and the latter, who are seen as uncivilized and backward (QUIJANO, 2005). Hence, the colonizers believe that, because they are more advanced, civilized and endowed with scientific knowledge, they are legitimately entitled to imposing their ways on the colonized (CASTRO-GÓMEZ, 2005).

In the coloniality of knowledge, the Global North universalizes local knowledge as if it were a neutral and superior truth (LANDER, 2005). In order for the Global South to develop and progress, it would need to adopt knowledge models from the Global North (DUSSEL, 2019) through the loss of local identity, with re-identification according to the needs of the Global North (MIGNOLO, 2018). The value of the colonized occurs insofar as they mimic the colonizers (QUIJANO, 2005).

Lastly, the coloniality of being came about with the myth of racial classification, according to which there was a hierarchy of peoples. The inferiority of the peoples of the Americas was created with a disguised coloniality, in that they were less rational and mature than Europeans (MIGNOLO, 2011). According to this logic, the colonizing race is considered "naturally" superior to the colonized, and in world capitalism, such a myth of modernity translates into the racial classification of work (QUIJANO, 2005).

Nowadays, after having replaced the English, French and Germans, who once occupied the position of being the main responsible for advancing modernity (MIGNOLO, 2011), the United States has become the predominant creator of modernity, bringing coloniality especially to Latin America. In the midst of the Americanization of the colonized during the Cold War, Latin Americans lost their roots and no longer had the right to even call themselves "Americans" (GALEANO, 2016, p. 18). For the United States, it was important to ensure at all costs that the Americas, including South and Central America, were not dominated by the communist enemy, which meant using U.S. influence over the region to prevent the advance of left-leaning governments (TOTA, 2000). Such pressure on Latin America resulted in the alignment of its countries - and also others in the Third World - with U.S. capitalist interests (ESCOBAR, 2004).

In response to such retrocession, decolonial authors have advocated a move away from the Eurocentric world, a movement called delinking (MIGNOLO, 2007), as the only form of local emancipation, since, as explained by Abdalla and Faria (2017), "hypermodernity imparts not emancipation without limits, but a worsening picture of poverty and inequality in several fields, including administration/management".

\section{METHODOLOGY}

In order to achieve the objective of the study, a historical research was carried out using a decolonial perspective. The decolonial option prescribes the unveiling of a colonial side to certain phenomena ignored and subalternized by modernity (MIGNOLO, 2011). In developing this type of research, we sought to tell an "alternative" story of the creation of the Advertising SelfRegulation System, showing how Eurocentric influences materialized during this process, with the objective of maintaining control of the Global North over the Global South (HEMAIS, 2019).

In this way, based on a critical analysis of the historical and colonizing construction of Western superiority and official consumerist history (FARIA and HEMAIS, 2018), the study questions the legitimacy of applying models created by the Global North (and in its interest) to the Global South, which has its own needs and particularities. The decolonialist perspective is suited to the present work because of its intrinsic agenda of criticizing - and resisting - the Western model of power, being and knowing (PRASAD, 2015). As advocated by Abdalla and Faria (2017): "In response to an enduring situation of asymmetry and injustice in the field of Management and Organization Studies, (MOS) sustained by the radicalization of universalization of Euro-American knowledge, as well as the corresponding subalternation of knowledge from the rest of the world, this article analyzes the marginal position and the potential of the decolonial perspective in Brazil". 
Prasad (2015) defends the adopting of post-positivist methodologies for qualitative research, but acknowledges the challenge of developing high quality works outside the positivist traditions. On the other hand, the author explains that applying non-positivist methodologies enriches the field of qualitative research, in a way that exposes ambiguities, tensions and interconnections with relevant debates (PRASAD, 2015).

The research relied on secondary data to unveil this alternative history, originating from different sources. Such data were collected from the annals of the 3rd Brazilian Congress on Advertising; books and articles on the history of Brazilian advertising and self-regulation; journalistic articles about facts and relevant events related to the studied topic; documents found at the Center for Research and Documentation of Contemporary Brazilian History (Centro de Pesquisa e Documentação de História Contemporânea do Brasil-CPDOC), located at the Getúlio Vargas Foundation (FGV), containing interviews and testimonies of key figures in the advertising sector of the period studied; and articles written by the main actors responsible for developing the Brazilian system of advertising self-regulation. Box 1 , in the following, briefly describes the main documents used for the article:

Box 1

Main Documents

\begin{tabular}{|c|c|c|c|}
\hline Document & Origin & Period & Quantity \\
\hline Journalistic Articles & $\begin{array}{c}\text { Folha de São Paulo } \\
\text { Brazilian Newspaper }\end{array}$ & $1970-1978$ & 6 articles \\
\hline Revista Propaganda & $\begin{array}{c}\text { ESPM Archives } \\
\text { São Paulo }\end{array}$ & 1976 & 1 edition \\
\hline Revista de Direito do Consumidor & $\begin{array}{c}\text { Editora Thomson } \\
\text { Reuters Archives }\end{array}$ & 1992 & 114 pages \\
\hline $\begin{array}{c}\text { Annals of the 3rd Brazilian } \\
\text { Congress on Advertising }\end{array}$ & Conar Archives & 1978 & 3 pages \\
\hline $\begin{array}{c}\text { Letter from Caio Domingues } \\
\text { to Geraldo Alonso (1978) }\end{array}$ & Conar Archives & 1978 & 4 statements \\
\hline Statements by Advertisers & CPDOC Digital Archives & 2004 & 1978 \\
\hline
\end{tabular}

Source: Elaborated by the authors.

The analysis of the collected data was carried out in two stages. First, the data were organized chronologically, following recommendations by Savitt (1980), Golder (2000) and Witkowski and Jones (2006), as well as according to key themes, such as ICC and IAA, consumerism in Brazil, formation of the Brazilian advertising area, and development of SBAP, including CBAP and Conar. For each theme, the following factors were taken into account: official marketing history, geopolitical context at the time and the decolonial perspective originating in Latin America. This type of organization made it possible to construct a timeline of events and contexts related to the main entities and key figures involved in the creation of SBAP and how they helped to shape the Eurocentric influence on the Brazilian self-regulatory system. In addition, the development of this timeline enabled us to establish whether or not relevant information was missing from the alternative story being told and, consequently, what information would be needed to fill possible time gaps (SAVITT, 1980; GOLDER, 2000).

In the second stage of the analysis, the data were analyzed and interpreted. During this process, the information was compared in order to find similarities and differences between the data. Although the analysis was of a descriptive nature, the interpretation focused on disclosing forgotten aspects of the history under analysis so as to show how the post-colonial process occurred.

\section{SEDUCTIVE IMPERIALISM: THE EUROCENTRIC INFLUENCE ON BRAZIL'S SELF-REGULATION SYSTEM}

The normative basis of CBAP, the Brazilian self-regulation code, along with Conar, forms SBAP, the Brazilian self-regulation system (ROCHA, 2012). First, it is important to understand the origin and the reasons - economic and geopolitical (TOMASHOT, 2015) - that led to the creating of a model for advertising self-regulation and how this model was internationalized (IAA, 2020a, 2020c). The second theme to be studied in this analysis focuses on the extent of the participation and influence 
of foreign entities in the Brazilian advertising sector throughout its history (RAMOS, 1985). Lastly, the creation of SBAP will be studied, focusing on its ethnocentric influences, explaining key events that occurred between the years 1976 and 1980 in particular.

\section{The Coloniality of Power: ICC, IAA and Advertising Self-Regulation}

Industrialization transformed the nature of companies, which became large corporations, and also of work, which ceased being rural and became urban, creating a proletarian class (LANDER, 2005). Salaried labor would be essential for guaranteeing the expansion of the mass consumption market (FURTADO, 1973). It was in this context of growth of the industry, on the one hand, and the search for its control by the State, on the other, that the ICC was born. When analyzing the minutes, speeches and procedures of the meetings in which the founding of the ICC was defined and organized - particularly those that occurred in 1919 and 1920 - one can perceive a colonialist, Eurocentric and racist discourse (TOMASHOT, 2015). By using the power of the few northern nations that composed it to legitimize itself universally, the ICC wanted to impose the "idea of race as an instrument of domination" (QUIJANO, 2005, p. 269).

From the very beginning, the ICC defends the idea that the progress of humanity starts with trade by "advanced," "civilized" nations (FAHEY, 1920, p. 21). In this way, a homogeneous and Eurocentric power structure is developed, reiterating the coloniality of domination and exploitation between white and non-white peoples (QUIJANO, 2005). The logic of mass consumption, essential to the corporations of the Global North, is dependent on colonialist logic, which, in turn, depends on the consolidation of the idea that the northern nations, which are superior and owners of the universal truth, are saviors who will take progress to the uncivilized, irrational Global South (DURAND, 2003; MIGNOLO, 2011).

A "universal truth" created by the official discourse of entrepreneurs is that the great obstacle to world prosperity is the number of laws imposed on them by their respective nations (FAHEY, 1921). The private sector's deregulation mentality strengthened during the interwar period, when the ICC developed its 1937 advertising self-regulation code (ABOUT, 2019). In the institution's words, "ICC's founders acted on their conviction that the private sector is best qualified to set global standards for business" (ICC, 2020a).

The expansion of the adopting of the 1937 code was due to the partnership between the ICC and the IAA (CELEBRATING, 2020), which have similarities with each other. The partnership's official discourse claims that it is a global association, with thousands of members in dozens of countries (JONES, 2000). However, its creation was restricted and took place at an exclusive New York club, the Harvard Club, in the presence of twelve executives (IAA, 2020d).

The defense of the self-regulation model is one of the major priorities of the IAA (JONES, 2000). The system of advertising self-regulation is explained by the fear of state intervention, which companies see as a threat in the competitive market (ROCHA, 2012). In order to legitimize the neoliberal movement, the system receives the guise of a neutral science, silencing relevant discussions such as protecting collective, economic, cultural and social interests. Corporations' profit interests are masked with supposedly scientific evidence and technocratic discourse, with positivist arguments that favor knowledge from the Global North (RAMSAY, 1992), strengthening the U.S.'s mission to internationalize its economic, neoliberalism-focused worldview (GRANDIN, 2010).

The defense of the universality of this model masks the interests of the nations and entities that have internationalized it. Such valorization of the endogenous is a constituent element of a broader colonizing movement, in which historically the Global North has imposed its socioeconomic premises on the Global South due to geopolitical interests, with the justification that it is providing modernity to the region, even if, along with that, it also imposes coloniality and its violence (MIGNOLO, 2011).

In the first half of the 1970s, Ralph Nader, one of the greatest U.S. consumerists of the time, began to strongly criticize the activity of multinationals from the Global North regarding their activities in the Global South in general, and in Latin America in particular (RALPH, 1973, p. 25). However, the so-called "international rights" of consumers met the wishes of consumers in the Global North. The neoliberal current states that consumption is indispensable for progress and democracy. The geopolitical face of this discourse and the fact that the democracy it defends applies to white males and colonizers in the Global North are masked (DURAND, 2003; GRANDIN, 2010).

As consumerist movements similar to those that occurred in the United States began to gain prominence in the Latin American media (RALPH, 1973) and as U.S. advertising agencies consolidated in the region (DURAND, 2003), the IAA intensified its 
activities in Latin America (IAA, 2020a, 2020c). In 1976, it would hold its World Congress in Buenos Aires, in response to consumer movements that were in the spotlight in the region, inviting war on consumer activists and state regulation (O MUNDO, 1976). The IAA's efforts in the Latin American region during the 1970s paid off. Between the 1970s and the 1980s, six councils, chambers and commissions regarding advertising self-regulation were created in South America, in addition to Mexico and El Salvador, according to models imported by the ICC and the IAA (CONAR, 2020).

The neoliberal self-regulation model advocates the defense of freedom of expression for advertisers and freedom of choice for consumers (JONES, 2000), with a focus on expanding the mass consumption of products and services in the Global North. As Hemais and Faria (2018, p. 360) explain, "mass consumption should be encouraged globally, and the American way of life is the standard of living desired by everyone. By expanding this consumerist model all over the world, the United States made it difficult to create another type of development through consumption and consumer protection, enunciated in the Third World."

\section{The Colonialities of Knowledge and of Being: the Formation of Brazilian Advertising}

The history of advertising in Brazil was influenced by foreign models well before the creation of SBAP, going hand in hand with the arrival of international commercial brands and models at the beginning of the 20th century, especially from the United States (OBERLAENDER, 1984). The importing of Eurocentric advertising knowledge was essential for constructing Brazilian advertising practices (COELHO, 2005), in addition to shaping Brazil's largest advertisers (RAMOS, 1985), several of whom would later become key figures in the creating of SBAP (DUAILIBI, 2005).

The exporting of U.S. advertising and marketing occurred due to the forecast of market saturation, which led several U.S. corporations and their advertising agencies to internationalize (DURAND, 2008). Due to the degrading of local knowledge and the imposing of new identities and paradigms from the Global North (ESCOBAR, 2004), there was an appreciation for foreign advertising professionals, which led to the importing of costly "talent," for the purpose of training national teams from U.S. agencies in Brazil (SIMÕES, 2006). Some advertisers, such as Sarmento (1990), have averred that U.S. know-how was indispensable for the "progress" of advertising in Brazil.

During that period, especially during the Second World War, Americanism was reinforced as a paradigm in the region, with the idealizing of the "American Way of Life" (COELHO, 2005) as a means to mitigate the German influence present in Brazil, especially in the south of the country. Companies from the U.S. were also encouraged to advertise with an appeal to support the Allies (TOTA, 2000). The period was also marked by the installation of several U.S. corporations in Brazil, such as Coca-Cola (SIMÕES, 2006). Also at the time, with incentives from the U.S. government, companies in that country increased the ads for their products in Latin America to the extent that such ads became responsible for most of the revenue derived from ads in Brazilian publications (DURAND, 2008).

With the advance of the Cold War, the ideological bipolarization of the world was cemented (GRANDIN, 2010). Brazil allied itself with the Western Bloc, with the predominance of U.S. geopolitics (HEMAIS and FARIA, 2018). At that time, advertising was truly massified and became a machine used to mold opinions and control information. The largest advertising agencies were multinationals that also worked for other foreign companies and created content that was detached from the Brazilian reality (OBERLAENDER, 1984). Walls between the West and the rest of the world were getting bigger and bigger, and the United States felt justified in carrying out a new witch hunt under the pretense of threat from malevolent countries (MALDONADOTORRES, 2008) - this time represented by the communists (TOTA, 2000).

National capital agencies would only grow after implementation of the civil-military dictatorship (SIMÕES, 2006). However, the Eurocentric mentality was already evident in the professionals from the sector. According to publicist Celso Japiassu, from Denilson, at that time it was difficult to identify the nationality of an agency by its name because it was common practice to give English names to advertising agencies even if they were funded with $100 \%$ Brazilian capital. Advertisers wanted to hide their national origin because they feared being seen as incompetent, unqualified or amateurish by their clients, which were mostly multinationals from the Global North, since "the company [...] of foreign origin had a deep contempt for the natives and their manifestations". 
Therefore, a sector "built upon a tropicalized English" was created (JAPIASSU, 1973), strengthening the idea of Northern superiority and Southern inferiority (MIGNOLO, 2011). The Eurocentric rational classification between the evolved (European) and the uncivilized (non-European) is, in the end, racial and, at its core, a racist classification established by those who have put themselves on a higher level (QUIJANO, 2005).

Throughout the formation of Brazilian advertising, which occurred mainly between the years 1910 and 1970 (DURAND, 2008), the U.S. model was praised, to the detriment of local production. The consequence has been that the entire Brazilian advertising model "is American in rules, in formation, in development, in grandeur, in history, in chronology, in antecedence. [...] The Hispanic contribution is practically zero" (COELHO, 2005). The marginalization of knowledge of the so-called Third World has stemmed from a process that universally standardized modern colonial capitalism and hierarchized world power according to racial classifications (QUIJANO, 2005).

\section{SBAP as a "Natural" Colonial Product}

The Brazilian Inter-Association Advertising Commission (Comissão Inter-associativa da Publicidade Brasileira) was created in 1977 (CORRÊA, 1990) with the specific mission of constructing the system of advertising self-regulation in Brazil. The ICC code of 1937, used as the basis for CBAP, was the first advertising self-regulation model in the modern mold (CORRÊA, 1990). Hegemonic models were created to meet the wishes and needs of white Europeans (ESCOBAR, 2004), who had become a synonym for superior knowledge and a more advanced society (QUIJANO, 2005).

The CBAP draft written by the Inter-Association Commission was drawn up by Mauro Salles and Caio Domingues (DOMINGUES, 1978). From the beginning, the drafters sought to incorporate the knowledge derived from codes adopted in other countries (CAVALCANTI, 2008). The central issue here is that applying the ethnocentric advertising self-regulation model to realities in the Global South generates a continuous tension between the formulation of models originating in one locale and applying them all over the world, and the need to respect different cultures and local realities (BROHMAN, 1995). In other words, in the stead of an alleged neutral and absolute truth, there is a hegemonic representation of the world seen from the perspective of the Global North (ESCOBAR, 2004). On the one hand, there is the Global North maintaining its control over the Global South via socioeconomic mechanisms; on the other, there are the colonized, who, historically regarded as backward, strictly follow the colonizers' model (MIGNOLO, 2011).

The commission brought together influential Brazilian advertisers of the time, among them Renato Castelo Branco, Geraldo Alonso, Luiz Macedo, Carlos Alberto do Carmo, Roberto Duailibi, José Alcântara Machado and Oriovaldo Vargas Löfler (CORRÊA, 2005). It is worth mentioning the formation of the U.S. mentality of the members of this commission throughout their careers (RAMOS, 1985).

Caio Domingues, for example, was described as "too American" for some (COELHO, 2005) and was trained at the U.S. advertising agency J.W. Thompson (RAMOS, 1972). A similar situation was that of Renato Castelo Branco, who, at Ayer, had worked with famous advertising names (SIMÕES, 2006), who, in turn, had been introduced to U.S. advertising models in the famous advertising department at GM at the start of the 20th century (REIS, 1990). Other members of the Inter-Association Commission had also begun their careers in advertising at U.S. agencies, which served as schools. Such was the case of Petrônio Corrêa (2005) and Luiz Macedo (2005), who had worked together at Grant Advertising from 1940 to 1950.

The coloniality of being begins with the world classification of race. In world capitalism, this myth of modernity translates into the racial classification of work. Thus, the good advertiser is the "Americanized" advertiser, shaped by U.S. standards of knowledge (QUIJANO, 2005; DURAND, 2008). A decades-long mimicry, especially of U.S. techniques, helped to naturalize the importing of foreign models without taking local needs into account, and prioritizing neoliberal geopolitical interests based on imperialist policies masked by the discourse of progress (CASTRO-GÓMEZ, 2005).

The code drawn up by the Inter-Association Commission was presented at the 3rd Brazilian Congress on Advertising (CORRÊA, 1990), which had several international participants and had the IAA as one of its official supporters (CAVALCANTI, 2008). The Brazilian code was also submitted at the 26th IAA World Congress (DOMINGUES, 1990), which took place just one month after the Brazilian event (IAA, 2020d). The code was approved at the world congress, and the IAA recommended it to participating countries that had not yet implemented their own self-regulatory systems (DOMINGUES, 1990).

The strong influence of international and foreign entities can also be seen in CBAP's statements, in which the main sources used for its development are verified. 


\section{Considering:}

[...]

- the recommendations of the ICC - International Chamber of Commerce and the guidelines of the ICC Code of Advertising Practice, originally drawn up in 1937 and revised in 1949, 1955 and 1966 and, finally, in 1973 during the Congress held in Rio de Janeiro, and whose terms were adopted by Brazil and 250 entities from more than 40 countries;

- the guidelines of the [IAA - International Advertising Association] and its World Congresses, especially those contained in its study "Effective Advertising Self Regulation," published in 1974, and the recommendations of the 25th World Advertising Congress held in Buenos Aires in 1976 (CONAR, 1978).

The advertising sector, formed according to the ideas and techniques of the United States (DURAND, 2008), consolidating colonialism from the knowledge of science as superior (LANDER, 2005), also adopted the discourse used by the Global North, differentiating colonizers from the colonized via the idea that development and progress are only achieved following the models of the superior "race" (QUIJANO, 2005). When talking about CBAP, Geraldo Alonso, president of the Inter-Association Commission, claims that is was a project "translated by the desire and the need of the so-called developed peoples" (ALONSO, 1978). Imperialist ideas involving an overvaluation of the North and a consequent undervaluation of the South (LANDER, 2005), were present throughout the development of SBAP.

Box 2, in the following, briefly explains the main colonial processes in the creation of SBAP:

\section{Box 2}

Summary of the Colonial Processes Involved in the Creation of SBAP

\begin{tabular}{|c|c|c|}
\hline What & How & When \\
\hline $\begin{array}{l}\text { The coloniality of power: } \\
\text { ICC, IAA and advertising } \\
\text { self-regulation }\end{array}$ & $\begin{array}{l}\text { ICC: creates a system of advertising self-regulation as a way to avoid } \\
\text { regulation by the state, with the supposedly universal argument of } \\
\text { prosperity through the free market. } \\
\text { IAA: the internationalization of the system took place as a response to } \\
\text { consumer movements, imposing, in an imperialist way, the autonomy } \\
\text { of advertising over consumer protection. }\end{array}$ & $\begin{array}{l}\text { 1937: creation of a "universal" } \\
\text { system of self-regulation } \\
\text { 1970s: imperialist } \\
\text { internationalization of the } \\
\text { system for Latin America }\end{array}$ \\
\hline $\begin{array}{l}\text { The colonialities of knowledge } \\
\text { and of being: the formation of } \\
\text { Brazilian advertising }\end{array}$ & $\begin{array}{l}\text { The importing of Eurocentric advertising knowledge was essential } \\
\text { for the construction of Brazilian advertising practices, in addition to } \\
\text { shaping the largest advertisers in Brazil. Several of these advertisers } \\
\text { would later become key figures in the creation of SBAP. Consequently, } \\
\text { a tropicalized U.S. sector was created, thus strengthening the idea of } \\
\text { the superiority of the Global North, and the inferiority of the South. }\end{array}$ & $\begin{array}{l}\text { 1910-1930: beginning of the } \\
\text { U.S. influence on Brazilian } \\
\text { advertising } \\
\text { 1940-1950: consolidation of } \\
\text { influence with the American } \\
\text { Way of Life } \\
\text { 1960-1970: growth of Brazilian } \\
\text { agencies with U.S. logic }\end{array}$ \\
\hline $\begin{array}{l}\text { SBAP as a "natural" product of } \\
\text { colonialities }\end{array}$ & $\begin{array}{l}\text { CBAP was drawn up by a group of Brazilian advertisers who had a U.S. } \\
\text { mindset and was based on foreign codes, especially the British. } \\
\text { After having been approved at a Brazilian congress, CBAP was also } \\
\text { approved at the IAA World Congress. } \\
\text { The advertising sector thus consolidated the colonialism of knowledge } \\
\text { of science as superior, differentiating the colonizers from the colonized } \\
\text { via the idea that development and progress can only be achieved by } \\
\text { following the models of the superior "race". }\end{array}$ & $\begin{array}{l}\text { 1977: Creation of CBAP } \\
\text { according to foreign logic } \\
\text { 1978: Approval of CBAP and } \\
\text { Conar by the Brazilian congress } \\
\text { sponsored by the IAA and by } \\
\text { the IAA congress }\end{array}$ \\
\hline
\end{tabular}

Source: Elaborated by the authors. 


\section{FINAL CONSIDERATIONS}

The objective of the present study was to analyze, from a decolonial perspective, how the Eurocentric model of self-regulation was incorporated into the creating of SBAP, which was formed by CBAP and Conar. To realize that objective, a historical research was conducted, which used secondary data in order to present a history related to the creation of that system, which is still scarcely discussed in the marketing literature in general, and consumerism, in particular.

Currently, even though the process of Eurocentric control over the Global South, especially Brazil, does not make use of outright violence - as occurred during the period of colonization - this process has succeeded at achieving its objective through a veiled fury, which restricts forms of thought that differ from that of the Global North (MIGNOLO, 2011). In the case presented, it seems that no alternative to controlling advertising in Brazil - other than via self-regulation according to the molds established by the North - was ever considered by the advertising sector when discussions about it were taking place.

In the case under analysis, coloniality is present in its three main representations: coloniality of power, of knowledge and of being (QUIJANO, 2005). Any kind of emancipation in the advertising sector, therefore, is compromised because the Eurocentric domination seems to be made in such a way as to curb any attempts to create a form of advertising that is de facto Brazilian - or even Latin American. This picture, however, is a reflection of a bigger plan, in which a large part of consumerist practice in Brazil seems to suffer from such Eurocentric domination (DURAND, 2003; HEMAIS and FARIA, 2018). Brazilian consumers consequently end up being defended by a consumerism that was hardly intended to meet their needs concerning corporate abuse, which would lead us to ask whether or not we are really being protected at all.

The marketing literature devoted to consumerism research is not very attentive to such geopolitical issues related to consumer protection. One explanation for this situation may be because the area refrains from questions that put the validity of its knowledge in check (FIRAT, 2010), given that such knowledge would be universal, as is all knowledge originating in the Eurocentric world (MIGNOLO, 2009). Discussing issues that might show a darker side of the history of marketing, therefore, would go against those principles and would require rethinking the area and its composition, in addition to its past. Instead of following that path, marketing seems to prefer to "deliberately" forget certain more "problematic" historical events (PATTERSON, BRADSHA and BROWN, 2008) in order to create an "official history" that calls "alternative histories" into question (SAUERBRONN and FARIA, 2009).

The perception that there is a geopolitics of domination behind consumerist actions, however, is easier to see for those who have experienced its violence, especially colonized peoples of the Global South. Hence, it is up to researchers of that locus of enunciation to discuss such problems in order to create spaces that allow us to express our concerns. However, for such discussions to proceed appropriately, they must not be externalized only in the Global South. It is important that we Southerners take them to the Global North so that we can dialogue with our peers from that locus in order to create alternatives to the Eurocentric order, in an attempt to validate knowledge originating in the rest of the world. It would not be meant to replace modernity with another form of modernity; the aim would be to foster conditions to make it possible to create a world where many worlds can coexist (MIGNOLO, 2011).

Although it is understood as relevant, the present study makes a small contribution in an attempt to better understand the phenomenon under analysis. Future research that strives to broaden the discussions addressed herein is encouraged. Given that the focus of the analysis developed herein had a historical perspective, one route to explore would be to do a study of Conar in order to verify if this organization still follows Eurocentric self-regulatory standards today and how this process occurs.

Finally, it should be noted that the decolonial perspective adopted in the present study should be used more by researchers in Brazil to explore other realities that are ignored by the marketing literature, but which are part of our history, nonetheless. Research that wants to make use of that critical vision to analyze Brazilian consumerism even further could, for example, study how international organizations influenced other local consumer institutions to adopt Eurocentric principles in their practices. However, it is hoped that the use of the decolonial perspective will go beyond consumer discussions, retelling a number of other forgotten Brazilian and Latin American histories, which are unlikely to be remembered by researchers from the North. Therefore, it is up to those in the South to rescue and appreciate past histories that are part of our essence. 


\section{REFERENCES}

ABDALLA, M.; FARIA, A. Em defesa da opção decolonial em administração/gestão. Caderno EBAPE.BR, Rio de Janeiro, v. 15, n. 4, Oct./Dec. 2017.

ABOUT us: ICC and the Code. Codescentre for Advertising and Marketing. Available at: <https://www.codescentre.com/about-us/>. Accessed on: July 10, 2020.

ALONSO, G. 1a Sessão Plenária, realizada em 17 de abril de 1978: Comissão Especial de Autoregulamentação e Painéis de Criação. In: CONGRESSO BRASILEIRO DE PUBLICIDADE, 3., 1978, São Paulo. Anais... São Paulo: Arquivo do CONAR, 1978. p. 15-16.

AUTORREGULAMENTAÇÃO dos publicitários é aprovada. Folha de S. Paulo, São Paulo, 21 abr. 1978, ano 57, n. 17.915, p. 22, Seção Economia.

BETING, J. A culpa de todos. Folha de S. Paulo, São Paulo, 18 jul. 1971, ano LI, n. 15.372, p. 24, Seção Terceiro Caderno.

BROHMAN, J. Universalism, eurocentrism, and ideological bias in development studies: from modernization to neoliberalism. Third World Quaterly, v. 16, n. 1, p. 121-140, 1995.

CASTRO-GÓMEZ, S. (Post)Coloniality for Dummies: Latin American Perspectives on Modernity, Coloniality, and the Geopolitics of Knowledge. In: MORAÑA, M.; DUSSEL, E.; JÁUREQUI, C. A. (Orgs.). Coloniality at Large: Latin America and the Postcolonial Debate. Durham/Londres: Duke University Press, 2008. p. 259-285.

CASTRO-GÓMEZ, S. ¿Qué hacer con los universalismos occidentales? Revista Ideação, n. 25, p. 39-76, 2017.

CAVALCANTI, A. R. Congressos Brasileiros de Publicidade I, II e III: Versão Compilada. 2008. Available at: <http://www.abapnacional. com.br/images/publicacoes/123_congressos.pdf $>$. Accessed on: July 10, 2020.

CAVALCANTI, M. F. R.; ALCADIPANI, R. International Development in the Brazilian Context in the 1950s and 1960s: A postcolonial reading of Guerreiro Ramos. Caderno EBAPE.BR, Rio de Janeiro, v. 14, n. 1, p. 12-23, jan./mar. 2016.

CELEBRATING 80 years of the ICC Marketing Code. New York: USCIB, 2017. Available at: <https://www.uscib.org/celebrating-80-years-ofthe-icc-marketing-code/>. Accessed on: July 10, 2020.

COELHO, E. E. Edeson Ernesto Coelho (depoimento, 2004). Rio de Janeiro: CPDOC, Associação Brasileira de Propaganda, Souza Cruz, 2005.

CONSELHO NACIONAL DE AUTORREGULAMENTAÇÃO PUBLICITÁRIA - CONAR. Código Nacional de Autorregulamentação Publicitária. Código e Anexos, 1978. Available at: <http://www.conar.org.br/ codigo/codigo.php>. Accessed on: July 10, 2020.

CONSELHO NACIONAL DE AUTORREGULAMENTAÇÃO PUBLICITÁRIA - CONAR. Conselho Nacional de Autorregulamentação Publicitária. 2020. Available at: <http://www.conar.org.br/>. Accessed on: July 10,2020

COHEN, L. A consumer's republic: the politics of mass consumption in postwar America. New York: Alfred A. Knopf, 2003.

CONSUMERISMO: um mal a ser evitado. Folha de S. Paulo, São Paulo, 28 ago. 1974, ano LIV, n. 16.605, p. 31, Seção Nova Mulher.
CORRÊA, P. Da auto-regulamentação publicitária: lineamentos de sua introdução no Brasil. In: BRANCO, R. C.; MARTENSEN, R. L.; REIS, F. (Orgs.). História da Propaganda no Brasil. São Paulo: T. A. Queiroz Editor, 1990. p. 45-54.

CORREAA, P. Petrônio Corrêa (depoimento, 2004). Rio de Janeiro: CPDOC, Associação Brasileira de Propaganda, Souza Cruz, 2005.

DOMINGUES, C. [Carta] 30 mar. 1978, São Paulo [para] ALONSO, Geraldo, São Paulo. 3f. Exposição de Motivos do relator da Comissão Interassociativa.

DOMINGUES, C. Disciplinar a ética na publicidade não é tarefa fácil. In: BRANCO, R. C.; MARTENSEN, R. L; REIS, F. (Orgs.). História da Propaganda no Brasil. São Paulo: T. A. Queiroz Editor, 1990. p. 39-44.

DUAILIBI, R. Roberto Duailibi (depoimento, 2004). Rio de Janeiro, CPDOC, Associação Brasileira de Propaganda, Souza Cruz, 2005.

DURAND, J. C. G. Formação e internacionalização da sociedade de consumo norte-americana (1870-1930). São Paulo: Eaesp GV Pesquisa, 2003.

DURAND, J. C. G. Formação do campo publicitário brasileiro (19301970). São Paulo: Eaesp GV Pesquisa, 2008.

DUSSEL, E. Eurocentrism and Modernity: Introduction to the Frankfurt Lectures. The Post Modern Debate in Latin America, Boundary 2, v. 20, n. 3, p. 65-76, 1993.

DUSSEL, E. Europe, Modernity, and Eurocentrism. Nepantla: Views from the South, v. 1, n. 3, p. 465-477, 2000.

DUSSEL, E. Globalization, Organization and the Ethics of Liberation. Organization, v. 13, n. 4, p. 489-508, 2006.

DUSSEL, E. Pedagogics of Liberation: A Latin American Philosophy of Education. Santa Barbara: Punctum Books, 2019.

ESCOBAR, A. Beyond the Third World: imperial globality, global coloniality and anti-globalization social movements. Third World Quaterly, v. 25, n. 1, p. 207-230, 2004.

FAHEY, J. H. Response by Mr. John H. Fahey. In: INTERNATIONAL CHAMBER OF COMMERCE. Organization Meeting of the International Chamber of Commerce: Paris, France June 23 to 30, 1920. Paris: International Chamber of Commerce, 1920. p. 19-21.

FAHEY, J. H. The International Chamber of Commerce. The Annals of the American Academy of Political and Social Science. The International Trade Situation, v. 94, p. 126-130, Mar. 1921.

FARIA, A.; HEMAIS, M., Historicizando o Novo Consumerismo Global Sob uma Perspectiva de Mundos Emergentes. Revista de Administração Contemporânea, Rio de Janeiro, v. 22, n. 4, p. 577-599, 2018.

FIRAT, A. Commentaries on the state of journals in marketing. Marketing Theory, v. 10, n. 4, p. 437-455, 2010.

FURTADO, C. A. Hegemonia dos Estados Unidos e o subdesenvolvimento da América Latina. Rio de Janeiro: Civilização Brasileira, 1973.

GABRIEL, Y.; LANG, T. The Unmanageable Consumer. 3 ed. London: Sage, 2015.

GALEANO, E. As veias abertas da América Latina. Porto Alegre: L\&PM, 2016. 
GOLDER, P. Historical method in marketing research with new evidence on long-term market share stability. Journal of Marketing Research, v. 37, n. 2, p. 156-172, 2000.

GLICKMAN, L. B. Buying Power: A History of Consumer Activism in America. Chicago/Londres: The University of Chicago Press, 2009.

GRANDIN, G. Empire's Workshop: Latin America, The United States, and the Rise of the New Imperialism. Nova lorque: Metropolitan Books, 2010.

HARVEY, D. A brief history of neoliberalism. Nova lorque: Oxford University, 2011.

HEMAIS, M.; FARIA, A. Highlighting the Darker Side of Liberal Internationalism for a Counter-Colonizing Consumerism. Latin American Business Review, v. 19, n. 3-4, p. 349-373, 2018.

HILTON, M. Social activism in an age of consumption: the organized consumer movement. Social History, Londres, v. 32, n. 2, p. $121-$ 143, 2007.

HILTON, M. The Death of a Consumer Society. Transactions of the Royal Historical Society. Cambridge, v. 18, p. 211-236, Dec. 2008.

HILTON, M. Prosperity for All: Consumer Activism in an Era of Globalization. Ithaca: Cornell University Press, 2009.

INTERNATIONAL ADVERTISING ASSOCIATION - IAA. Our History. 2020a. Available at: <https://iaaglobal.org/uploads/general/History. pdf $>$. Accessed on: July 10, 2020.

INTERNATIONAL ADVERTISING ASSOCIATION - IAA. Join the most influential Global Marcom Network. 2020b. Available at: <https:// www.iaaglobal.org/>. Accessed on: July 10, 2020.

INTERNATIONAL ADVERTISING ASSOCIATION - IAA. Advertising SelfRegulation, the New ICC Marketing Code, and the IAA. 2020c. Available at: $<$ https://iaaglobal.org/leadership/advertising-self-regulation-thenew-icc-marketing-code-and-the-iaa>. Accessed on: July 10, 2020.

INTERNATIONAL ADVERTISING ASSOCIATION - IAA. For the Record. 2020d. Available at: <https://iaaglobal.org/ uploads/general/PastWPs-Chairmen-Con-and-ConferencesUPDATED_180906_164142. pdf $>$. Accessed on: July 10, 2020.

INTERNATIONAL CHAMBER OF COMMERCE - ICC. Advertising and Marketing Communications Code. 2020. Available at: <https://iccwbo. org/publication/icc-advertising-and-marketing-communicationscode/>. Accessed on: July 10, 2020.

JAPIASSU, C. A criatividade de sabor tropical. Jornal do Brasil, Rio de Janeiro, 01 dez. 1973, ano LXXXIII, n. 237, p. 4, Caderno B.

JONES, J. P. (Ed.). Advertising Organizations and Publications: A Resource Guide. Thousand Oaks: Sage Publications, 2000.

JOVENS denunciam poluidores do ar. Folha de S. Paulo, São Paulo, 18 de maio 1970, ano XLIX, n. 14.946, p. 16, Primeiro Caderno.

KELLY, D. The International Chamber of Commerce. New Political Economy, v. 10, n. 2, p. 259-271, 2005.

KOTLER, P. What Consumerism means for marketers. Harvard Business Review, v. 50, n. 3, p. 48-57, 1972.

LANDER, E. Ciências Sociais: saberes coloniais e eurocêntricos. In: LANDER, E. (Org.). A colonialidade do saber: eurocentrismo e ciências sociais. Buenos Aires: Clacso, 2005. p. 21-53.
MACEDO, L. V. G. Luiz Macedo (depoimento, 2004). Rio de Janeiro, CPDOC, Associação Brasileira de Propaganda, Souza Cruz, 2005.

MALDONADO-TORRES, N. A topologia do Ser e a geopolítica do conhecimento: modernidade, império e colonialidade. Revista Crítica de Ciências Sociais, n. 80, 2008.

MALDONADO-TORRES, N. Analítica da colonialidade e da decolonialidade: algumas dimensões básicas. In: BERNARDINOCOSTA, J.; MALDONADO-TORRES, N.; GROSFOGUEL, R. (Orgs.). Decolonialidade e pensamento afrodiaspórico. Belo Horizonte: Autêntica, 2018.

MALDONADO-TORRES, N. Ethnic studies as decolonial transdisciplinarity. Ethnic Studies Review, 42, n. 2, p. 232-244, 2019.

MIGNOLO, W. Epistemic Disobedience, Independent Thought and Decolonial Freedom. Theory, Culture \& Society, v. 26, n. 7-8, p. 159-181, 2009.

MIGNOLO, W. The Darker Side of Western Modernity: Global Futures, Decolonial Options. Durham: Duke University Press, 2011.

MIGNOLO, W. Decoloniality and Phenomenology: The Geopolitics of Knowing and Epistemic/Ontological Colonial Differences. Journal of Speculative Philosophy, v. 32, n. 3, p. 360-387, 2018.

MIGNOLO, W.; WALSH, C. On Decoloniality: Concepts, Analytics, Praxis. Durham: Duke University Press, 2018.

O MUNDO está mudando: e o que a propaganda tem a ver com isso? Revista Propaganda, São Paulo, ano XX, n. 235, p. 106-107, Feb. 1976.

OBERLAENDER, R. História da propaganda no Brasil. Rio de Janeiro: Shogun Arte, 1984

PASQUALOTTO, A. S.; CAUDURO, L. K., Sistemas de autorregulamentação da publicidade: um quadro comparativo entre países. Revista da Faculdade de Direito da UFRGS, Porto Alegre, v. 35, n. esp., p. $207-$ 230, Dec. 2016.

PATTERSON, A.; BRADSHAW, A.; BROWN, S. 'Don't forget the fruit gums, chum': marketing under erasure and renewal. Marketing Theory, v. 8, n. 4, p. 449-463, 2008.

PRASAD, A. Crafting Qualitative Research: Working in the Postpositivist Traditions. Nova lorque: Routledge, 2015.

QUIJANO, A. Colonialidade do poder, eurocentrismo e América Latina. In: LANDER, E. (org.). A colonialidade do saber: eurocentrismo e ciências sociais. Perspectivas latino-americanas. Rio de Janeiro: Clacso, 2005. p. 227-278. (Coleção Sur Sur).

RALPH Nader critica as multinacionais. Folha de S. Paulo, 14 set. 1973, ano LIII, n. 16.158, p. 25, Seção Economia.

RAMSAY, I. O controle da publicidade em um mundo pós-moderno. Revista de Direito do Consumidor, São Paulo, v. 4, n. esp., p. 26-41, 1992.

RAMOS, R. História da propaganda no Brasil. São Paulo: Universidade de São Paulo - Escola de Comunicações e Artes, 1972.

RAMOS, R. Do reclame à comunicação: pequena história da propaganda no Brasil. 3. ed. São Paulo: Atual, 1985.

REIS, F. São Paulo e Rio: a longa caminhada. In: BRANCO, R.; MARTENSEN, R. L.; REIS, F. (orgs.) História da propaganda no Brasil. São Paulo: T. A. Queiroz Editor, 1990. p. 1-6. 
ROCHA, R. H. M. da, Modelos de regulamentação: reflexões para um eficiente controle jurídico da publicidade no Brasil. Direito \& Justiça, Porto Alegre, v. 38, n. 2, p. 200-212, July/Dec. 2012.

ROSA, A. R.; ALCADIPANI, R. A terceira margem do rio dos estudos críticos sobre administração e organizações no Brasil: (re)pensando a crítica a partir do pós-colonialismo. Revista Administração Mackenzie, São Paulo, v.14, n. 6, p. 185-215, Nov./Dec. 2013.

ROTFELD, H. J. Confusions, contexts, and foundations for understanding advertising regulation as related to the research of Jean J. Boddewyn. International Studies of Management \& Organization, v. 40, n. 4, p. 94-103, 2010-2011.

SANTOS, B. S. Um discurso sobre as ciências. 6. ed. São Paulo: Cortez, 2009.

SARMENTO, A. M. As agências estrangeiras trouxeram modernidade, as nacionais aprenderam depressa. In: BRANCO, R. C.; MARTENSEN, R. L.; REIS, F. (Org.). História da Propaganda no Brasil. São Paulo: T. A. Queiroz Editor, 1990. p. 20-24.

SAVITT, R. Historical research in marketing. Journal of Marketing, v. 44, n. 4, p. 52-58, 1980.
SAUERBRONN, F.; FARIA, A. A utilização do método histórico em pesquisa acadêmica de marketing. Estratégia e Negócios, v. 2, n. 2, p. 78-95, 2009.

SIMÕES, R. A propaganda no Brasil: evolução histórica. São Paulo: ESPM, 2006.

TIEMSTRA, J. P. Theories of Regulation and the History of Consumerism. International Journal of Social Economics, Bingley, v. 19, n. 6, p. 3-27, 1992.

TOMASHOT, S. R. Selling Peace: The History of the International Chamber of Commerce, 1919-1925. 2015. Doctoral Dissertation (Doctor Degree in Philosophy). Georgia State University, Atlanta, 2015.

TOTA, A. P. O imperialismo sedutor: a americanização na época da Segunda Guerra. São Paulo: Companhia das Letras, 2000.

WITKOWSKI, T.; JONES, B. Qualitative historical research in marketing. In: BELK, R. (Ed.). Handbook of Qualitative Research Methods in Marketing. Edward Elgar: Cheltenham, 2006.

ZULZKE, M. L. Abrindo a empresa para o consumidor: a importância de um canal de atendimento. 4. ed. Rio de Janeiro: Qualitymark, 1997.

Laís Rodrigues

ORCID: https://orcid.org/0000-0002-1038-7996

Master in Law from the Pontifical Catholic University of Rio de Janeiro (Puc-Rio) and in Business Administration from the Business School (IAG) from the Pontifical Catholic University of Rio de Janeiro (Puc-Rio); Ph.D. student in Business Administration at the School of Administration (IAG) at the Pontifical Catholic University of Rio de Janeiro (Puc-Rio); Publisher of digital books from Agência Hashtags, Rio de Janeiro- RJ, Brazil. E-mail: Irdossa@gmail.com

Marcus Wilcox Hemais

ORCID: https://orcid.org/0000-0001-9181-8446

Ph.D. in Business Administration from the Coppead Institute of Administration at the Federal University of Rio de Janeiro (UFRJ); Graduated in Business Administration from the Pontifical Catholic University of Rio de Janeiro (PUC-Rio); Master in Business Administration from the Pontifical Catholic University of Rio de Janeiro (PUC-Rio); Adjunct Professor in the Department of Administration at the Pontifical Catholic University of Rio de Janeiro (PUC-Rio); Deputy Coordinator of the Graduate Program in Administration at the Pontifical Catholic University of Rio de Janeiro (PUC-Rio), Rio de Janeiro- RJ, Brazil. E-mail: marcus.hemais@iag.puc-rio.br 